This item was submitted to Loughborough's Research Repository by the author.

Items in Figshare are protected by copyright, with all rights reserved, unless otherwise indicated.

\title{
Cold War cultural transactions: designing the USSR for the West at Brussels Expo ‘58
}

PLEASE CITE THE PUBLISHED VERSION

http://dx.doi.org/10.1080/17547075.2017.1333388

\section{PUBLISHER}

(C) Taylor \& Francis

\section{VERSION}

AM (Accepted Manuscript)

\section{PUBLISHER STATEMENT}

This work is made available according to the conditions of the Creative Commons Attribution-NonCommercialNoDerivatives 4.0 International (CC BY-NC-ND 4.0) licence. Full details of this licence are available at: https://creativecommons.org/licenses/by-nc-nd/4.0/

\section{LICENCE}

CC BY-NC-ND 4.0

\section{REPOSITORY RECORD}

Reid, Susan E.. 2019. "Cold War Cultural Transactions: Designing the USSR for the West at Brussels Expo ‘58”. figshare. https://hdl.handle.net/2134/25158. 


\title{
Cold War Cultural Transactions: Designing the USSR for the West at Brussels Expo '58"
}

\section{Susan E. Reid}

\section{Author Bio}

Susan E. Reid is Professor of Cultural History in the Department of Politics, History and International Relations, Loughborough University. She has published widely on painting, visual and material culture, gender and consumption in the USSR. Recent publications include, "Still Life and the Vanity of Socialist Realism: Robert Fal'k's Potatoes 1955," Russian Review 76/3(2017); "Cold War Binaries and the Culture of Consumption in the Late Soviet Home,” Journal of Historical Research in Marketing 8/ 1 (2016); and "Makeshift Modernity: DIY, Craft and the Virtuous Homemaker in New Soviet Housing of the 1960s," International Journal for History, Culture and Modernity 2/2 (2014).

s.e.reid@lboro.ac.uk

\begin{abstract}
Focusing on the Cold War Expo in Brussels 1958, this article takes the metaphor of "design diplomacy" as a lens through which to explore the dilemmas of Soviet exhibition planners charged with designing a modern image of the USSR at the World Fair. Seeking ways to represent the advantages of socialism to foreign, especially Western publics, the exhibition organizers began to question established Soviet tradecraft in the production of mass exhibitions, concluding instead that if the USSR was to make itself understood by the capitalist "other," it must adopt selectively the idiom of its audience and interlocutor. The Soviet 'self was constituted in relation to two main "others": the USA, whose pavilion was adjacent to the Soviet one; and the anticipated public, about whom the Soviet designers knew little. As in diplomatic transactions, the art of persuasion demanded negotiation and compromise, resulting in a degree of transculturation and cross-fertilization.
\end{abstract}

Keywords: Cold War, exhibition design, cultural diplomacy, transculturation, Brussels World Fair, Expo ’58, Soviet pavilion

The metaphor of "design diplomacy" provides a useful lens through which to examine how international relations have been materialized and played out in the multi-media form of international expositions, and, conversely, how the design of such expositions helped shape international relations. This essay turns this lens on the USSR's self-presentation at Expo 58 in Brussels, the first World Fair of the Cold War era, held for six months from April 17, 1958. Focusing on the ways the Soviet exhibition planners conceived the task of presenting the USSR and socialist system to international and especially Western publics, it explores how the Expo provided a kind of miniaturized model of global geopolitics, where the two "world camps" of 
Capitalism and State Socialism contested but also negotiated their claims for modernity, working out strategies for future moves, not only in terms of the message but also of the medium of exhibition design.

The analogy of diplomacy usefully directs attention to the importance of dialogue and intercultural communication even in such adversarial contexts as the Cold War. Diplomacy requires not only an assertion of difference, but also an anticipation of and accommodation with one's interlocutor's agendas, culture, and idiom; a willingness to compromise; and a tacit agreement to observe the rules of civility and polite conversation. In the rhetoric used by the Belgian hosts, the Brussels Expo was to be an exercise in international relations by cultural means. It would, they hoped, engender a "new international atmosphere” (GARF9470/1/1, 6) of dialogue, reconciliation and rapprochement between the two camps, overcoming the tensions of the Cold War and enabling greater global cooperation to address some of the pressing problems of the age through the peaceful application of science and technology (NARA306/71A2101/159; NARA306/1011/1; Schroeder-Gudehus and Cloutier 1994, 158).

From their inception, World Fairs, dedicated to celebrating and promoting industrial and technological progress, served as sites of exchange, transmission and “internationalization.” They accelerated the process of technology transfer and spread a particular form of modernity. Thus, it has been proposed that they should be viewed as sites of Cold War “convergence” (Péteri 2012). The geometric figure of convergence implies, however, a rather mechanistic, deterministic model (Reid 2010). To think about the complex, multidimensional transactions under way at the World Fair it may be more productive to consider the Cold War Expo as a "contact zone," a term drawn from cultural anthropology and linguistics to describe social spaces where disparate cultures “meet, clash, and grapple with each other” (Pratt 1992, 4). The idea of the contact zone emphasizes cultural transfer or "transculturation"-a form of appropriation and bricolage, whereby (usually subordinate or marginal) groups select and invent from materials transmitted to them by a dominant or metropolitan culture. Envisaging multiple connections and cross-fertilizations, it foregrounds the reciprocal, “interactive, improvisational dimensions of colonial encounters” (Pratt 1992, 7) and the way that subjects are constituted in and through their relations with each other. Furthermore, it emphasizes that the outcomes of convergence may be new 
hybrid cultural products: creole languages, for example, which enable communication without being identical with the “imperial” language (Pratt 1992, 6-7; Clifford 1997, 192). By analogy, the effects on Soviet idiom in the Cold War Expo's contact zone with the West would not necessarily result in its absorption into the language and values of the Western "other” (ideological “convergence” or rather conversion), but in a new hybrid cultural entity and enhanced possibilities for effectively communicating its worldview to the other camp.

In what follows I will explore the USSR exhibition planners' emerging understanding of their task at Brussels and of the challenges it presented to the established tradecraft of Soviet exhibition planning. The USSR pavilion was one of the most visited of the whole Expo, with a daily average of 120,000 visitors (GARF9518/1/590, 95, 248-49). But as the Soviet organizers themselves were painfully aware, it was a work in progress. It bore the scars of its birth in the midst of both the internal struggles of destalinization at home in the USSR and its bloc, and of the shifting demands of the global conflict and competition in the period of "peaceful coexistence," the new more relaxed phase the Cold War entered after Stalin's death. Expo '58, I shall argue, was not only a site of “diplomatic” persuasion, but also a school in the arts of international public relations, exhibition design, and multimedia cross-cultural communication; the forms of modernity it diffused included the pavilion architecture, specific exhibits, and also the mode of exhibition display itself.

This article will focus on the latter: how the Soviet exhibition planners conceived the contents and mode of display to go inside their pavilion, rather than on the architecture of the pavilion itself. It attends, in particular, to their representation of living standards, home, and consumption, terrain the capitalist West had already claimed as its own (Reid 2002, 211-52; Castillo 2010). Learning from both friends and adversaries, Soviet image-makers honed the weapons of soft power and visual strategies of cultural diplomacy and ideological warfare and began to shape up an image of the Soviet Union as a modern world power, an image it continued to develop and disseminate at subsequent fairs. Taking place in the late 1950s, the very moment when Soviet design was born as a profession, the encounters, negotiations, and deliberations in the Brussels contact zone were a formative experience for the emerging field of Soviet exhibition design (Rozhdestvenskii 1959; Brodskii 1959, 4041; TNAFO371 159601; Kliks 1978; Maistrovskaia 2009; Reid 2006; Hutchings 
1976). This process involved internalization and transculturation of aspects of the Cold War capitalist “other’s” approach to self-promotion as well as of its symbols.

The Soviet approach to its self-presentation at Brussels was shaped by the terms of engagement at the World Fair set by the Belgian Expo committee, which sought to establish common ground amongst participants as a basis for reconciliation. The paper will address, first, the way that the allocation of directly adjacent territory to the leaders of the two Cold War camps made it necessary for Soviet planners to anticipate how their neighbour, the USA, would present itself; and second, the umbrella theme, “a new humanism,” also set by the Belgian hosts, to which all participants were obliged to refer. It will then turn to a third factor that influenced how the Soviets conceived their task: the anticipated viewer. For the "diplomacy" conducted through exhibition design was highly visible, even spectacular. Unlike the key historical events of government-to-government diplomacy, Brussels '58 did not only involve meetings of important state representatives behind closed doors or through secret telephone conversations. The Expo was a dialogue conducted on a world stage before an audience that both sides courted.

\section{Common Ground}

Peaceful coexistence and cultural offensive: an exhibition not of goods, but of ideology

$<$ Fig. 1 $>$

The meanings of the term "diplomacy" include: "to do something with tact, discretion, delicacy, sensitivity to the possibility of causing ill will.” One dictionary (Dictionary.com) gives the example: “Seating one's dinner guests often calls for considerable diplomacy.” At Brussels, the Belgian hosts drew up their "seating plan” with the intention to make the USA and USSR engage in dialogue at the table, assigning the leaders of the two world camps contiguous plots (Haddow 1997, 95). The proximity of the Soviet and American pavilions compelled the designers to take account of each other and to anticipate the comparisons visitors would inevitably draw (GARF9470/1/22, 13; Devos 2009). The “seating plan” drawn up by the Belgian hosts was also, potentially, a massive diplomatic faux pas. But their fears that it might provoke a very undiplomatic showdown between the two great powers were trumped 
by their sense of showmanship and concern to satisfy business sponsors as well as the general public, seeking entertainment at the fair (Schroeder-Gudehus 1994, 157-79).

Notwithstanding the official rhetoric of reconciliation and cooperation, it was plain to all that Brussels would be a test of Cold War soft power, where the two antithetical "world camps" of socialism and capitalism would engage in what Frederick Barghoorn $(1960,87)$ termed the “cultural offensive.” Both would use the fair to set out their stalls for their competing, ideologically opposed models of progress and globalization. The fair would be "a site of struggle between the ideas of two worlds, capitalist and socialist," where "each country would demonstrate and propagandize its way of life” (GARF94710/1/27, 27). Soviet intelligence spelled out the hostile ideological intentions behind the Belgian commission's rhetoric of reconciliation:

Brussels is an arena in which two worlds will struggle. They will strive to show the advantages of the capitalist order over the socialist. This idea is undoubtedly the main one for the organizers of the exhibition. (GARF9470/1/21, 162)

The USA-Soviet sources reported—had also declared their intentions to "defend [their] cause, to fight against the communists," by demonstrating "the superiority of the American way of life” in direct comparison with the USSR (GARF9470/1/21, 199; GARF9518/1/588, 14-15; NARA306/1011/1). Howard Cullman, General Commissar of the US pavilion, pronounced that since "millions of visitors will compare the USA and USSR," the exhibition "provides us and our friends in the free world with an unprecedented opportunity to show, as vividly as possible, our ideology, way of life and hopes for the future. ...The free nations must make use of every possibility they have at their disposal to underline the meaning of the freedom they possess” (GARF9470/1/21, 199; GARF9518/1/588, 14-15; NARA306/1011/1). The Soviet organizers concluded: "We know that the Americans are preparing an exhibition not of goods, but of ideology” (GARF9518/1/588, 204). As a secret memo to the Party Central Committee warned, all the Western participating nations would treat the World Fair as a competition between the socialist and capitalist systems and would do battle in the realm of ideology, values, and meanings; they aimed to show “not what they produce, but what they represent” (GARF9518/1/588, 14, 27; cf. Schroeder-Gudehus 1994)). 
The Soviet government formally accepted the invitation to participate in the Brussels fair on June 6, 1956 (GARF9470/1/22), recognizing both the challenges and the opportunities it presented. With nearly fifty states participating and a projected 3550 million viewers, Brussels "presents us with opportunities for propaganda such as we have surely never had in the post-war period in Europe” (GARF9470/1/27, 159$60)$. In addition to the exhibition itself, the year-long publicity surrounding it afforded unprecedented channels for the Soviet Union to propagandize state socialism openly and legally in the West, using the West's own airwaves and official media (GARF9470/1/3, 41-42; 9470/1/27, 127, 159-60; GARF9470/1/21, 205; GARF $9470 / 1 / 22,13)$. It was also a vital occasion for the Soviet Union to countervail the bad press it had received abroad as a result of its suppression of the Hungarian revolution in 1956 (GARF9470/1/21, 162).

A number of state committees, departments and ministries were charged with preparing for this major propaganda campaign. A former Deputy Minister of the Ministry of Machine Tool Production and Automation, Dmitrii Ryzhkov, was appointed General Commissar of the Soviet section. The overall planning of the Soviet sector fell to two organizations: the USSR Chamber of Commerce under M.V. Nesterov, and the State Committee for Cultural Links with Foreign Countries, headed by former Pravda editor Georgii Zhukov (GARF9470/1/3; GARF9470/1/21). These bureaucracies had differing conceptions of the nature of the opportunity Brussels provided, and of how best to set out the Soviet stall. Nesterov's Chamber of Commerce was oriented more towards using the Expo for developing trade links, and it appears to have been steeped in entrenched practices with venerable origins in late nineteenth-century trade fairs. Zhukov's Committee for Cultural Links, meanwhile, was concerned with ideological influence and cultural offensive. As an exhibition of competing ideologies and ways of life, rather than a trade fair, Expo 58 demanded taking account of the Western viewer's preconceptions and their exhibitionary culture (GARF9470/1/21, 205; GARF9518/1/588, 26-29, 36-44; Reid 2010). The archives reveal a clash of bureaucratic cultures and institutionalized approaches between these two bodies. This reflected, in microcosm, the wider battles raging back home in the USSR since Stalin's death in 1953, between the friends and foes of destalinization, reform, and modernization. 
Peering through the net curtain

$<$ Fig. $2>$

From the outset, the USSR exhibition organizers recognized that the juxtaposition of their sector with that of the USA impelled them to take account of the American plans when designing their pavilion and the displays to go in it. However, information about American intentions was very hard to glean (NARA306/71A $2101 / 159,4)$. The better part of diplomacy is discretion-the careful management of the relation between secrecy and publicity. Likewise, secrecy, timing, and showmanship were central principles in preparations for Brussels. World Fairs compelled participating nations to engage in a balancing act between concealment and advertisement, both to arouse curiosity and preserve the element of surprise on opening, and to protect trade secrets and technological innovations (Rydell 1993, 20809).

This secrecy affected a key question: the architectural design of the pavilion. ${ }^{1}$ Here, the Soviet organizers had to move ahead on the basis of informed guesses in the crucial planning stages (GARF9470/1/22, 64; GARF9470/1/21, 200-1). An open competition was announced in July 1956, from which the simplest design was chosen, a glazed parallelepiped emphasizing rationality, classical rigour and dignified restraint (Vasil'ev 1957, 43-6; Polianskii and Ratskevich 1958; GARF 9470/1/16, 102-4; GARF 9470/1/22, 34-45; GARF 9470/1/21, 199-200; GARF 9470/1/16, 104). The architects, a young collective including Andrei Boretskii and Anatolii Polianskii, explained that they consciously eschewed virtuoso gestures, such as the Western nations were expected to indulge in, for: "it would not befit us, the Soviet Union, to perform such extravagant tricks” (GARF9470/1/22, 39-40).

While disdaining to enter competition on such frivolous terms, the Soviet designers recognized that the contents of their pavilion must nevertheless "resonate polemically" with their American neighbour; for visitors to the exhibition could not avoid comparing the two adjacent expositions. Archival documents reveal the intense interest the Soviet planners took in every aspect of how America would present itself in their displays (e.g. GARF9470/1/21, 200-5; GARF9470/1/25, 74-77; GARF9518/1/588; Reid 2010). However, a dearth of detailed intelligence left them guessing at their adversary’s intentions for the interior displays. The Soviet response 
was based primarily on prejudice, rumors, and projections extrapolated from past performance. The imagined "Amerika" the Soviets anticipated became a constitutive part of the Soviet self-representation (GARF9470/1/21: 205; GARF9518/1/588: 207; GARF9470/1/25: 76-77).

Soviet sleuths managed to glean information that the narrative of the US pavilion would focus on Fordist modernity and the American way of life, emphasizing two main ideas: living standards/prosperity and freedom/democracy (GARF9518/ 1/588, 204). This was to be expected, since prosperity and democracy had already been coupled in the USIA's “People’s Capitalism” campaign (Hixson 1997, 121-50). The US display would try to make capitalism appear more humane by laying claim to values that were positively identified with socialism: the equitable distribution of "political freedom, protection of the individual and opportunity for his growth, advancement in social welfare, cultural opportunity, and a fair share of material goods” (NARA306/1011/1, 2; NARA306/71 A2101/161; Rydell 1993, 198).

Of one thing the Soviet planners were certain: the American pavilion would, Zhukov announced, “definitely have material about the good life [represented by] two cars to one family, a separate house with fifteen rooms, their wardrobe, and a mechanical kitchen where everything is electronic” (GARF9518/1/588, 204). Another report confirmed that the American kitchen would be featured in the form of two or three working fitted kitchens (GARF9470/1/9, 154). This, too, was a reasonable expectation given that, since the 1940s, the USIA had made extensive use of show homes and "American kitchens” saturated with labor-saving technology in its European propaganda campaigns promoting the "American way of life” (Castillo 2005, 261-88; Castillo 2010; Cieraad 2009, 113-37). Model homes showcased American consumer goods while exemplifying the "humanism" of Marshall Plan materialism, People’s Capitalism, and consumer democracy in such a way as to appeal to the stereotypical European "man in the street" and, above all, "woman in the home.” Many other nations at Brussels also used model homes to demonstrate their national ideals and way of life as well as their consumer goods (Floré and de Kooning 2003, 319-40).

Zhukov's intelligence about US plans proved inaccurate, however. To widespread surprise, the USA chose not to include a full-scale model home to show off the American way of life, but limited itself to displaying “Islands of Living.” The 
decision to adopt an understated, soft sell approach resulted in part from a perceived need to redress European perceptions of America as a vulgar, consumerist parvenu by emphasizing, cool modernist design and high culture, and thus to lay claims to world cultural leadership in the field of high design (Haddow 1997, 153-68; Castillo 2010, 139-70; Rydell 1993, 203-ff.; Morris 1959). The understatement of affluent consumerism was also a matter of "diplomacy," in the sense of tact towards impoverished European populations. USIA-sponsored opinion surveys of European reception of American displays at international exhibitions had taught an important lesson: that America's material abundance and advanced technology must be rebranded for European consumption as a concern for the good of man, and, particularly, woman: "What is often called our 'materialism' is really only a means to a greater humanism” (NARA306/1050/7). Thus, the Brussels display should not be commercial, boastful, or didactic, US advisers indicated. It "should not belabor the obvious by playing up American wealth, power, machinery or gadgets.”

(NARA306/1011/1)

Soviet intelligence also anticipated that the Americans would "inevitably" represent America as a land of democracy, freedom, and equality. (GARF9518/1/588, 204-5) They would express the idea of democratic freedom in a number of oblique ways, such as special listening booths where visitors could listen to music of their choice, whereby “free choice” was equated with personal and political freedoms (Bol'shakov 1959, 28). On this score, Soviet intelligence was right: the rhetoric of freedom, individual choice, candour, ease, and spontaneity was expressed both by Edward Durrell Stone's pleasure-dome architecture and by Peter Harnden and Bernard Rudofsky’s seemingly unstructured, fragmentary display in the interior, set out like a swimming pool, with lounge chairs and ice cream, where one could relax, eat, drink, and watch fashion shows. (Rydell 1993, 206-11; Hixson 1997, 143; Haddow 1997, 110; Scott 2007). Visitors reportedly said that they felt "complete and unrestricted freedom in the U.S. Pavilion" (NARA 306/1011/1), and appreciated "the friendly, gay atmosphere” (NARA 306/71A2101/159, 29). Everything combined to suggest that this was a place for entertainment, relaxation, indulgence, and play (Haddow 1997; GARF9470/1/21, 200-1; GARF9470/1/25, 74; GARF9518/1/588, 207; Scott 2007). 
The design of the USA pavilion was premised both on a notion of the “American spirit," identified with openness and naturalness, and on a set of ideas about the specificity of exhibitions and about the nature of the viewer and his/her visit agenda. These understood the World Fair as a spectacular and dynamic multisensory medium of mass communication akin to that quintessentially modern experience, tourism (Urry 1990, 4-10; Scott 2007). The fair-goer, it assumed, had come to have a good time, to relax and be entertained. Ideas must therefore be conveyed not through theoretical concepts or abstract precepts but through concrete examples, images and tangible things.

In contrast to other mass media an exhibit best conveys abstract ideas and intuitive feelings through the skilful arrangement of carefully chosen objects, not through the written word. The best way to sell America is the "soft pitch"... All in all, the visitor must be pleased, flattered and amused. The minute he feels that he is being "educated" or "fed a line" the battle for his mind is lost. The Fair visitor, whether he be a streetcleaner or a university professor, goes to the Fair for entertainment. The didactic approach is not the way to reach him in that state of mind. (NARA306/1011/1, 9)

In these respects, the US pavilion epitomized some important trends in the design of World Fairs. First, since the beginning of the century such fairs had increasingly shifted away from edification and a "culture of production” towards mass entertainment (Rydell 1993, 116; Nye 1994, 141; Clasen and Rockwell 1968). Already at the 1939 New York World Fair, the ideal viewer was conceived as a "citizen-tourist," whose gaze was directed towards experiences that reaffirmed the centrality of consumption and leisure (Rydell 1993, 130; Urry 1990). Second, it exemplified the increasing importance, in the postwar period, of the idea of information and the use of communications technology and multisensory bombardment (Colomina 2001). The Soviet planners learned in advance how cuttingedge cinematic technology would be harnessed to present the American way of life; the chief "hook and propaganda device" would be a film America, Land and People projected in 360 degrees in a Circarama (Disney), which was to be shown for the first time outside the USA (GARF9470/1/9, 154). The viewer, placed in the center, would feel like a participant in the events shown on screen (GARF9470/1/25, 76-77). 
"Socialist humanism": the Soviet response to the general theme

Common ground among the Cold War adversaries was imposed not only spatially_by contiguity — but also conceptually: by the umbrella theme set by the Belgian exhibition organizers, "for a more human world.” According to the Commissar General, each nation was to demonstrate "its own conception of happiness and of the paths to attaining it” (Devos 2015, 154, n.2; Haddow 1997, 94-95). All were to demonstrate how scientific progress would improve human life for all. The common message was summed up: "Hope, Happiness and Humanism under the shadow of the atom." The fair must express "hope that man, on the threshold of the Atomic Age, may find a better means of achieving human understanding and peace” (NARA306/71A2101/159; NARA306/1011/1).

Western accounts of Brussels, both contemporaneous and historical, have drawn a stark dichotomy between the US and Soviet pavilions. According to Walter Hixson, while the Americans "respected" the fair's theme of "a new humanism," the USSR, by contrast, “ignored” it (Hixson 1997, 144). And while “The Americans seemed to be saying ... 'Relax a little and learn something of how we live,"” the Soviets "filled their exhibition with machine tools, model hydroelectric dams, and statistics on industrial growth, as if to say, 'We are large, we are powerful, we have science and industry...And we owe it all to communism."” (William Anderson quoted in Hixson 1997: 144-45;) These and other accounts imply that while the US was modern, dynamic, and responsive to its audience, the USSR doggedly pursued a didactic approach that was now outdated (Schroeder-Gudehus 1994: 168-69; Alloway 1961, 44-6).

The selection of exhibits and design of the displays was undoubtedly compromised as a result of internal divisions between forces of innovation and institutional inertia, modernization and Stalinism. However, we should be aware that the incoherence and overkill ascribed to the USSR pavilion in Western accounts was a common Cold-War othering trope. The contemporary and retrospective evaluations of the competing pavilions' was just as much terrain for a Cold War battle of representations as were the exhibits themselves. Moreover, the condescending opinions of professional journalists and experts do not reflect the contemporary response of the lay public. US surveys during and after the fair found the USA lagging worryingly far behind the USSR and other socialist pavilions in mass 
popularity. Much to the consternation of the US Information Agency, visitors flocked to the USSR pavilion. In the first three months, of the total 10,549,227 visitors to the Expo, over seven million (around three quarters) visited the USSR pavilion (GARF9518/1/590, 95, 248-49). Surveys of visitor satisfaction supplemented quantitative with qualitative evidence; they indicated that visitors to the fair were more interested in and impressed by the Soviet pavilion than by the US one. One USIA survey found "evidence that the Soviet Pavilion had greater favourable impact on visitor attitudes than did that of the US, despite apparently more frequent doubts about the credibility of the Soviet presentation” (NARA306/1011/2; NARA306/1011/1).

If Western reports acknowledged the public's interest in the Soviet pavilion, they generally ascribed it to Sputnik alone, a view that has been repeated in historical accounts (Schroeder-Gudehus 1994; Hixson 1997, 149). But for the Soviets, foreign fascination with Sputnik was not enough. The space-wonder might help pull in and impress the visitors, but what mattered was that they should take away the main message about the systemic superiority of socialism: what Soviet progress under socialism did for man (Bol'shakov 1959). This required engaging on the common ground established by the Expo's umbrella theme, and doing so in terms that would be understood by “ordinary” Western viewers: by addressing such issues as living standards, housing, and consumption, and by adopting a mode of display that would engage and accommodate Western popular exhibitionary culture.

Contrary to established views (Hixson 1997; Schroeder-Gudehus 1994), the Soviet planners conducted their deliberations in close reference to the umbrella slogan of the fair. They sought to embody the theme of hope, happiness, humanism and benevolent science, demonstrating socialist humanism and progress in the service of humanity and world peace (GARF9470/1/27; GARF9470/1/9; GARF9518/1/588, 14, 27). Since capitalist propaganda would try to demonstrate the superiority of the capitalist system in regard to the theme of "human happiness," the Soviet display must also show how, under socialism, man was "at the centre of all its state institutions, all industry, of all art” (GARF9470/1/3, 56-61; GARF9470/1/21, 159-62; GARF9518/1/588, 27). Visitors must, furthermore, take away an understanding that the socialist path to progress was not only more “democratic," but faster (a message it was particularly important to project to the World Fair's virtual public in the 
developing world, whom the USSR was avidly cultivating). Only the Soviet socialist system was fully able to apply the benefits of scientific and technological advance to the good of human beings (GARF9470/1/3, 7; Moscow News (1957), cited in NARA 306/1011/1; GARF9470/1/27, 173-75; Novikov 1958, 24).

The remainder of this essay will question Hixson and others' Cold-War assumption of essential, immutable difference, focusing instead on negotiation and cross-fertilization. Notwithstanding substantive, systemic, ideological differences in the message conveyed, there was more room, in the contact zone of the world fair, for dialogic accommodation and transculturation between Soviet and Western approaches than has often been assumed.

\section{Soviet Model Homes}

<Fig: 3 >

Not unlike the Americans, the Soviets illustrated the theme of progress and human happiness by emphasizing rising mass living standards and their effect on the lives of individuals and families. They aimed "to show how, on the basis of universal peace, a well-provided life is created for every person” (GARF9470/1/27, 152-59). Consumption and leisure were prominent themes in the Soviet displays and accompanying promotional imagery. A section was dedicated to "Objects of Popular Consumption,” including textiles, clothing, shoes, wine, chocolate, and other luxuries. It aimed to demonstrate the concern of the workers' state to raise workers' living standards and the diversity and high quality of Soviet consumer goods (GARF9518/1/588, 2-10; GARF9470/1/27, 133-36).

Yet even as the USSR joined battle on terms which the USA and its European Marshall Plan recipients had claimed as their own (De Grazia 2005; Castillo 2010), it remained vital to emphasize the specifically socialist route to achieving higher living standards for the greatest number of people: not only through individual but collective consumption, welfare, services, social benefits, the right to rest, state maternity and childcare provision, and importantly, through social housing (GARF9470/1/27, 15259). Given that housing was a major social and economic issue throughout the postwar world, this was a point on which it could appeal to hearts and minds on both 
sides of the Iron Curtain, as well as in the developing world.

In the Soviet pavilion's socialist take on the Expo theme of humanism and progress, the image of mass housing construction played a central role. A monumental painting by Alexander Deineka, For Peace (1958), set the tone by identifying the Soviet peace agenda, progressive technology, and socialist modernity with the benefits of urban construction. Photographs and statistics told of the reconstruction of war-damaged cities, and the construction of new mass housing regions, schools, and hospitals. Above all, the intensive industrialized housing campaign launched by Khrushchev on July 31, 1957 served as a platform for demonstrating the party-state's concern for ordinary people's welfare and the advantages of central planning (GARF9470/1/27, 139-49; TsK KPSS 1957).

The exhibition planners were concerned to make Soviet promises and achievements in the realm of housing less abstract and more immediate to the viewers' imagination. Soviet agencies had already taken an interest in the uses that Western nations made of model homes as a display format. In November 1957, they even invited the London Daily Mail to bring its "Ideal Home” Exhibition to Moscow for 1958 (TNABW2/532). At Brussels, the USSR pavilion included two life-size models of furnished apartment interiors representing the new standard, prefabricated, small-scale flats designed for single-family occupancy, recently put into mass production. They were fully furnished in a conservative modern style, and included kitchens where one could see domestic equipment including refrigerators, vacuum cleaners, and other electric appliances (GARF9470/1/16, 299; RGAE635/1/369, 15; Meeren 1958, 29-34). Thus, the viewer moved from photos and figures representing the scale of mass housing construction into the interior of an individual dwelling, where they might imagine the domestic comfort and joys of "private life" enjoyed by the Soviet family in housing provided by the state and public purse.

The Soviet organizers were well aware of the contradictions and pitfalls of this approach; in adopting domestic space, and specifically a home designed for an individual nuclear family, as a site to project Soviet ideals and achievements, they were raiding the rhetorical arsenal and idiom of the capitalist adversary, poaching a symbol closely identified with “Amerika”. Believing their (erroneous) intelligence that the Americans would “definitely" show a model home (GARF9518/1/588, 204), they were also nervous that this strategy of adopting the Cold War Other's idiom 
could backfire. How would the display of prefabricated industrialized mass housing resonate with the foreign audience, especially in light of anti-Soviet propaganda and the comparative context? “As regards showing apartments,” Kuznetsov warned,

in regard to the construction industry we are not ahead. It is better to show the reconstruction of cities destroyed in the war. Here, the city in ruins; there, as it is today. Or take the South West region of Moscow: to show who lives there. In the West they wrote that this little town is being constructed for ministers and functionaries. You're not going to amaze them with the fact that so many apartments have been built. (GARF9518/1/588, 207)

Zhukov was also worried about how a display of Soviet model homes would be received in the comparative, international context of the Brussels fair. "It will not be convincing and will arouse ridicule....Moreover, it is necessary to think about the things that will resonate polemically with the American ones.” (GARF 9518/1/588, 204) Compared to the separate house of fifteen rooms, with two cars and an electric kitchen-which Zhukov's sources predicted the US pavilion would "definitely" use to demonstrate prosperity — these standard, minimal-specification apartments might not, they feared, persuade the foreign viewer that the USSR was the land of abundance and high living standards for all.

To be sure, the kitchen equipment fell far short of the American "Atomic" and "Miracle" kitchens exhibited around Europe (and shown in Moscow the following year), as well as of Jacques Dupuis’ futuristic Electric House shown in the Belgian sector at Brussels (Floré and de Kooning 2003; Shaginian 1964). However, such kitchens were received by European publics as science fiction (Cieraad, 2009). The Soviet kitchen, by contrast, represented a more realistic and attainable improvement on most Europeans' kitchens in the 1950s. It is telling that three years later, the British press described the Soviet trade fair at Earl's Court (1961) as a “paradise for housewives," with its exhibits including refrigerators, washing machines, vacuum cleaners and other household items "which Soviet women can acquire for affordable prices_cheaper than such things in London” (Daily Sketch 1961, cutting in GARF 9518/1/611, 96). The Belgian design press in 1958 also acknowledged that although the furniture in the interior settings did not represent cutting-edge design like that exhibited in the US pavilion, it was more likely to appeal to mass taste (Meeren 1958). 


\section{Public Relations: learning from the enemy and anticipating the viewer in the contact zone}

The third and final condition to consider, which shaped the presentation of the Soviet "self," was the nature of the anticipated mass international audience, before whom the competition between East and West was played out and which both sides courted. Zhukov and his allies were beset by questions about how best to persuade the unknown Western audience and ensure that their message would not get lost in translation. And like the Americans, they were concerned to do so diplomatically, tactfully, in such a way that visitors would have their minds changed without realizing it. I proposed above that international expos might be considered "contact zones" where, in the process of intercultural communication, local or national idioms underwent transculturation and hybridization. This final section considers the effect of contacts both with foreign (especially Western) viewers and with foreign practices of display, marketing, and public relations.

It was one thing to tell the story of progress under the socialist system for an audience of Soviet citizens, already familiar with and able to decode it. But, the Soviet designers worried, how to represent the Soviet path to progress in ways that would be compelling to a potentially hostile Western audience? How might they demonstrate the dynamics of progress through time and its systemic causes - the Revolution, party guidance, and socialist central planning - in the visual form of an exhibition, and in such a way that the foreign audience would stop, look, and understand? (GARF9470/1/21, 205-8; GARF9518/1/588, 2-10)

The Soviet organizers recognized that the intercultural obstacles to communicating their message about the system-specific origins of Hope, Happiness and Humanism included the assumed prejudices and false consciousness of the Western viewer, long subjected to anti-Soviet propaganda. For example, they wanted to emphasize the right to labour, guaranteed in the Soviet constitution, but Western viewers, enslaved by the alienated conditions of capitalist production and brainwashed by capitalist propaganda about Soviet oppression, might misinterpret this. Zhukov worried: "But do Western people understand that labour is the main element of happiness?” (GARF9518/1/588, 204; GARF 470/1/9, 156) They were fearful that viewers would project their ossified stereotypes onto the Soviet display, orientalizing it as the backward other of capitalist modernity, fears which the Western 
accounts discussed above proved justified. Regarding the important story of socialist progress in the countryside and the modernization of agriculture, for example: "It is not enough to say we have ploughed up x number of hectares.... They don't care a damn about that. They [just] recall the Russian peasant in bast shoes and a ragged peasant’s coat.” (GARF9518/1/588, 204)

It was vital, Zhukov argued, to find exhibition strategies to counter such Western stereotypes, to break through the blinkers of false consciousness, and to build defenses against anti-Soviet propaganda into the exhibition (GARF9518/1/588, 26). For example, US disinformation was sure to represent Soviet life in terms of standardization and de-individualization. The need to contradict this slander made it essential to emphasize the individual and everyday life, on which Zhukov insisted. His colleague Kuznetsov confirmed:

\begin{abstract}
Abroad they write that here we have barracks and standardization and that individuality is suppressed. Therefore we need to show somehow that here the individual is ascendant and flourishes. ... In the West they constantly try to prove that under socialism, and even more under communism, the individual is reduced to a faceless number. On the contrary, we need first to show the conditions for the development of the individual and then starting out from showing [individual] people we can then make generalizations.
\end{abstract} (GARF9518/1/ 588, 192-206)

The Soviet planners started out from an assumption that Western viewers, subjects of capitalism, were the antithesis of the Soviet public. The latter was widely constructed as the "most reading people," committed to learning and self-improvement. The West European public, by contrast, had different expectations of a day out at the fair and a different culture of exhibition viewing. They were "not like the Chinese, who study every question in detail” and "not as we understand [the public] in the USSR, [where] a kolkhoz farmer or worker from a factory will stand by the conveyor belt with a notebook and study.” While "there might be one or two students looking for answers or to improve their qualifications, the rest of the visitors will not come looking for further education” but merely to pass time. “Therefore we must have radio, television, give out free literature, so that they take away the impression of superiority of the Soviet order in all areas.” (GARF9470/1/21, 207-8)

But how well did the Soviet organizers know the Western mass viewer, to whose interests their exposition had to appeal, and whose short attention span and 
distracted mode of viewing it had to accommodate? They had very limited direct contact with ordinary people in the capitalist West, and lacked systematic market research on which they might draw. To overcome their knowledge gap, the Soviets took advice from socialist allies and the Belgium-USSR Friendship Society. More surprisingly, they also adopted the market research methods of the capitalist enemy, enlisting the services of a Belgian public relations consultancy, identified in the Russian stenographers' report as "Pabli Sintez"-possibly a mis-rendering of “Publicité” (GARF9470/1/10, 147-78; GARF9518/1/588, 192).

The advertising agency's report advised the Soviet organizers that, in demonstrating Soviet economic progress, the exhibition must show that, "The brand 'Made in the USSR' is able to compete on world markets with international products.” (GARF9470/1/10, 161) More broadly, they advised the Soviets to "penetrate into the psychology of your interlocutor and accommodate yourself to it as best you can” (GARF 9470/1/10, 148; Siegelbaum 2012, 128, n.28). This marketing psychology, the conventional wisdom of public relations, is arguably also the basis of diplomacy.

Significantly, the public the Soviet planners imagined with the help of the PR firm was little different from the fair-goer hailed by the US pavilion. Like tourists, they came not for edification but for entertainment and relaxation, a day out at the fair, and a souvenir to take home-precisely the experience the American exhibit offered in its pleasure dome. Just as American advisers had cautioned their own designers, direct propaganda had to be avoided at all costs because it was likely to backfire (GARF9470/1/21, 161):

Foreign readers don't like to read a lot or for long....We love agitation, but the foreign reader won't tolerate it. Therefore our brochure must be short and, in light of what the foreign reader is used to, we must attend to such media as cinema, television, posters - that which gives pleasure and from which they can obtain a dose of positive information about the Soviet Union. (GARF9470/1/21, 168)

The mode of address, the visual language, and the syntax of the display all had to take account of the foreign public's exhibitionary culture, shaped, they assumed, by modern capitalist modes of communications (admass) and display (department stores) with their multisensory bombardment. The viewer was imagined as suffering from what Beatriz Colomina (2001, 6-29) has diagnosed as a kind of collective Attention 
Deficit Disorder. This, in turn, made it necessary to keep pace with the international trend towards interactive and dynamic displays. "Everything must turn, move, wink, catch the eye,” said Zhukov (GARF9518/1/588, 207). Rather than lecture or argue a case, the exhibition should lure the viewer "using the style of tourism.” Just as the US pavilion sought to convey a sense of ease, the consultants advised the Soviets to adopt a relaxed, unconstrained, and personalized manner. Visitors must feel welcome in the Soviet pavilion as in a good hotel; the foreign public should be met, metaphorically, with a smile, and "every visitor must feel that he is being greeted individually" so that when they left the pavilion they would feel a pang of homesickness for the Soviet Union and would say: “you feel most at home in the USSR pavilion.” (9470/1/10, 172-3)

The Belgian consultants also urged their Soviet client to take account of differences among the viewers and accommodate their prejudices, predictable responses, and general ignorance about Russia. Reproducing conventional gender stereotypes, they advised targeting women. Female visitors would be ignorant but “curious... and often driven by simple instinct.” Once their curiosity was aroused they would want to talk about it. While men were "always interested in politics and international affairs," and would come to the exhibition seeking confirmation of their preconceived ideas, women would pay more attention to the everyday life of the Soviet individual, while ignoring statistics about the growth of industry and trade. "Lovers of piquant detail, women will want to know about the life of women in the USSR. The housewife is bound to take an interest in how the housewife lives in the USSR.” Just as numerous publications and exhibitions of the 1950s personified the American way of life in the female form of the pushbutton housewife, so too the Soviet way of life was to be represented in such a way as to hail women in their roles as mothers, wives, homemakers, and consumers. Therefore, the exhibition must engage women first, and through their mediation, reach and influence men (GARF9470/1/10, 147-50). The PR firm’s advice evidently convinced Zhukov and his colleagues, confirming their own instincts and gendered assumptions. According to Kuznetsov, "The [exhibition] plan must be very clever but also simple and lively....Along comes a housewife wanting to know how a housewife lives in the Soviet Union, what kind of stove she has, how she swaddles a baby...how we live” (GARF9518/1/588, 193). Trying to imagine the European visitor to the Soviet 
pavilion for the purpose of planning the display, Zhukov's Committee for Cultural Links, just like the US planners for Brussels, envisaged her in stereotypically female form.

The exhibitionary culture of the anticipated viewer had implications both for what the Soviets should show and how: the mode of display. The Western viewer was given to scepticism rooted in a Cartesian tradition of "seeing is believing," the PR firm warned. Therefore, an emphasis on visual evidence was essential (GARF9470/1/10, 154). Zhukov concurred. "Western people are used to maximum visual aids. It is very hard to reach them with abstractions.” (GARF9518/1/588, 205) His assistant Kuznetsov added, "In the West, their thinking about abstract concepts is primitive. They love to feel and look. This aspect has to be kept in mind.” (GARF9518/1/588, 205-6) All this demanded a different mode of display from that which was customary back home for the Soviet public. The culture of the anticipated foreign viewer and her putatively low level of intelligence made a dynamic and multisensory approach necessary, appealing directly to sight and touch rather than abstract thought, using entertaining and amusing devices to grab and hold their attention. Animation and working models were vital to animate the displays (GARF9470/1/22, 38; GARF9470/1/21, 207). A non-didactic, soft sell approach was required, to minister a drop of information with a spoonful of sugar. "The display must be precise, engaging, and not boring, so that when a person has been in our pavilion he will involuntarily feel what is Soviet power, the Soviet land, whether he wants to or not" (GARF9470/1/21, 207 (emphasis added)). Above all, "Visitors to the exhibition should not receive some kind of seminar at it.” (GARF 9518/1/588, 207) A Soviet journalist with a reputation for bold innovation, Vasilii Zakharchenko (drafted in to bolster Zhukov's efforts to modernize and internationalize display practice in face of the Chamber of Commerce's resistance) declared: "We, the host, must not only broadcast, but also smile, joke, engage in conversation, and not assume the role of a schoolteacher. ”(GARF9470/1/11, 172-76; GARF9518/1/588, 20, 53, 55; GARF9470/1/10, 92) Zakharchenko’s comment, as Lewis Siegelbaum has noted (2012, 127), would not be out of place on Madison Avenue. Indeed, the approach Zhukov sought to adopt, alongside the feminized address the PR firm advocated, had more in common than hitherto acknowledged with the American pavilion, with its 
focus on the individual as the beneficiary of progress, on personal life, and on leisure, pleasure, and ease. Both were aiming at the same imagined viewer.

\section{Conclusion}

The Soviet self-representation at Brussels took shape in tandem with the exhibition planners' growing understanding of the dual "other": both the expected and actual display by its Cold War adversary, the USA; and the international, especially Western, public. Responding to what they thought they knew about the American plans, encouraged by Western PR consultants, and taking on board the Western “other's” anticipated prejudices about the Soviet Union, Zhukov and his team identified an approach that focused on the benefits of socialism as they were felt by the individual in everyday life. The problem of trans-systemic and transcultural communication was not only a matter of the message, however, but also of the medium. To appeal to the Western viewer required a more entertaining and spectacular approach: avoiding didacticism and making the displays as visual, immediate, and dynamic as possible. A new set of images of a reformed, more human-faced socialist modernity was accompanied by the beginning of a shift toward greater appeal to pleasure and emphasis on visual communication.

While subsequent exhibitions such as in New York (Rozhdestvenskii 1959) the following year and Expo '67 in Montreal (Eco 1986 [1967]) lie beyond the scope of this article, Brussels served as a training ground for Soviet display professionals, compelling them to measure themselves against international standards, and promoting appropriations and rapprochements both in the culture of display and in the iconography of progress. The more flexible and innovative institutions and individuals involved in the Soviet exhibition design came to understand that effective and persuasive communication across the Cold War divide required diplomatic compromise and accommodation. The Soviet display at the World Fair must capture the capitalist West's rhetorical arsenal, assimilate display modes and symbols it had made its own, and turn them against it. As in diplomatic negotiations, if the USSR was to be heard and understood in the way it wanted to be, it had to compromise and ventriloquize, strategically adopting the idiom of the Cold War adversary and translating itself into a visual language the other could comprehend. 
The juxtaposition of America and the Soviet Union may not have resulted in the reconciliation, on the West's terms, which the Belgian hosts had hoped to engineer. It did, however, make dialogue and inter-referentiality unavoidable. As in Pratt's contact zone, new hybrid identities and creole modes of communication were forged in the process of transculturation. The Soviet representation of its "self" was constituted both through the internalization of the imagined other and by selective syncretic assimilation of the other's symbolic language.

\section{Acknowledgements}

This paper draws on a Cold War International History Project working paper (Reid 2010). An early version was presented at the symposium From "Soft" to "Hard" Power? Changing Visions of Diplomacy by Design from 1945 Onwards, Brighton University, 27 November 2015. My thanks to the convenors and guest editors of this Special Issue, Verity Clarkson and Harriet Atkinson.

The research was supported by the Leverhulme Trust and the AHRC.

\section{Image Captions}

1. General Plan of Expo '58. Collection of Dep. Architecture \& Urban Planning, Ghent University

2: USSR (left) and USA (right) pavilions. Postcard 1957. Courtesy Rika Devos.

3: Model apartment displayed in USSR pavilion (RGAE635/1/369: 15). Printed with kind permission of the Russian State Archive of the Economy.

\section{References}

Alloway, Lawrence. 1961. “USSR at Earl’s Court: The Image,” Design 154 (October): 44-6.

Barghoorn, Frederick. 1960. The Soviet Cultural Offensive: the Role of Cultural Diplomacy in Soviet Foreign Policy. Princeton, N.J.: Princeton University Press.

Bol'shakov, Ivan. 1959. Vsemirnyi smotr: uspekh SSSR na vsemirnoi vystavke v Briussele. Moscow: Izvestiia.

Brodskii, Boris. 1959. "Vystavke nuzhen stsenarist," Dekorativnoe iskusstvo SSSR (12): 40-41.

Castillo, Greg. 2010. Cold War on the Home Front: The Soft Power of Midcentury Design. Minneapolis: University of Minnesota Press.

Castillo, Greg. 2005. "Domesticating the Cold War: Household Consumption as Propaganda in Marshall Plan Germany,” Journal of Contemporary History 40(2): 261-88.

Cieraad, Irene. 2009. “The Radiant American Kitchen: Domesticating Dutch Nuclear Energy,” in Oldenziel, R. and Zachmann, K. (eds) Cold War Kitchen:

Americanization, Technology and European Users. Cambridge, MA: MIT, 113-37. 
Clasen, Wolfgang, and Rockwell, Erwin. 1968. Exhibitions, Exhibits, Industrial and Trade Fairs. New York: Praeger/Architectural Press, 1968.

Clifford, James. 1997. "Museums as Contact Zones," in Routes: Travel and Translation in the Late Twentieth Century. Cambridge, Mass.: Harvard University Press, 188-219.

Colomina, Beatriz. 2001. "Enclosed by Images,”, Grey Room 02 (Winter 2001): 629.

Cooke, Catherine. 2007. "Modernity and Realism: Architectural Relations in the Cold War.” In Russian Art and the West, edited by Rosalind P. Blakesley and Susan E. Reid, 172-94. De Kalb: Northern Illinois University Press.

De Grazia, Victoria. 2005. Irresistible Empire: America's Advance through $20^{\text {th }}$ Century Europe. Cambridge, Mass: Belknap Press of Harvard University Press.

Devos, Rika and de Kooning, Mil. 2006. L'architecture moderne a l'Expo 58: "Pour un monde plus humain”. Brussels: Fonds Mercator/Dexia.

Devos, Rika. 2009. "A Cold War Sketch. The Visual Antagonism of the USA vs. the USSR at Expo 58.” Revue Belge de Philologie et d'Histoire 87: 723-42.

Devos, Rika. 2015. “'Let us now invest in peace.' Architecture at Expo 58 in Resonances of War,” in Devos, Rika, Ortenberg, Alexander, and Paperny, Vladimir. (eds) Architecture of Great Expositions 1937-1959. Aldershot: Ashgate, 133-160.

Eco, Umberto. 1986 [1967]. “A Theory of Expositions” in Travels in Hyperreality, 291-307. San Diego: Harcourt Brace Jovanovich.

Floré, Fredie, and de Kooning, Mil. 2003. “The Representation of Modern Domesticity in the Belgian Section of the Brussels World's Fair of 1958,” Journal of Design History, 16 (4): 319-40.

Gradov, Georgii. 1959. "Cherty budushchego v arkhitekture Briussel’skoi vystavki 1958 g.,” Arkhitektura SSSR (2): 48-62

Haddow, R. 1997. Pavilions of Plenty: Exhibiting American Culture Abroad in the 1950s. Washington: Smithsonian Institution Press.

Hixson, Walter L. 1997. Parting the Curtain: Propaganda, Culture and the Cold War, 1945-1961. Houndmills: Macmillan Press.

Hutchings, Raymond. 1976. Soviet Science, Technology, Design: Interaction and Convergence. London: OUP.

Kliks, Rudol'f. 1978. Kliks, R.R. 1978. Khudozhestvennoe proektirovanie ekspozitsii. Moscow: Vysshaia shkola

Maistrovskaia, M.T. 2009. "Rudol’f Kliks i ekspozitsionnyi dizain,” in Problemy dizaina v.5 . edited by NII Teorii i istorii izobrazitel’nykh iskusstv. Artproekt 2009: 93-115.

Morris, Hugh L. 1959. “All-State Splitnik: Overseas Home Exhibits Scored as Non-typical,” Washington Post and Times Herald, March 21.

Nikolaev, I. S., and Mel'nikov, N. P. 1963. Vsemirnaia vystavka v Briussele 1958. Arkhitektura, konstruktsiia, formy pavil'onov. Moscow: Gosstroiizdat.

Novikov, A. 1958. "S utra i do vechera," Ogonek, no. 24 (June 8): 24.

Nye, David. 1994. “Electrifying Expositions: 1880-1939.” In Fair Representations: World's Fairs and the Modern World, edited by Robert W. Rydell and Nancy Gwinn, 140-56. Amsterdam: VU University Press. 
Péteri, György. 2012. "Sites of Convergence: The USSR and Communist Eastern Europe at International Fairs Abroad and at Home,” Journal of Contemporary History 47(1): 3-12.

Polianskii, Anatolii, and Ratskevich, Iurii. 1958. "Pavil’on SSSR na Vsemirnoi vystavke 1958 g. v Briussele,”Arkhitektura SSSR (5): 32-41.

Pratt, Mary L. 1992. Imperial Eyes: Studies in Travel-Writing and Transculturation. London: Routledge.

Reid, Susan E. 2010. “The Soviet Pavilion at Brussels ‘58: Convergence, Conversion, Critical Assimilation, or Transculturation?” Cold War International History Project, working paper 62. Washington, D.C.: Woodrow Wilson International Center for Scholars.

Reid, Susan E. 2002. “Cold War in the Kitchen,” Slavic Review 61(2): 211-52.

Reid, Susan E. 2006. "Khrushchev Modern: Agency and Modernization in the Soviet Home,” Cahiers du Monde russe 47(1-2): 227-68.

Rozhdestvenskii, Konstantin. 1959. “Oformlenie dvukh vystavok,” Tvorchestvo (10): 5-9.

Rydell, Robert W. 1993. World of Fairs: The Century of Progress Expositions. Chicago: University of Chicago Press.

Schroeder-Gudehus, Brigitte, and Cloutier, David. 1994. "Popularizing Science and Ecology during the Cold War: Brussels 1958.” In Fair Representations. World's Fairs and the Modern World, edited by Robert W. Rydell and Nancy Gwinn, 15779. Amsterdam: VU University.

Scott, Felicity D. 2007. “An Eye for Modern Architecture.” In Lessons from Bernard Rudofsky: Life as a Voyage, edited by Architekturzentrum Wien, 172-210. Basel: Birkhäuser Verlag.

Shaginian, Marietta. 1964. Zarubezhnye pis'ma. Moscow: Sovetskii pisatel'.

Siegelbaum, Lewis. 2012. “Sputnik Goes to Brussels,” Journal of Contemporary History 47(1): 120-36.

TsK KPSS, Sov. Ministrov SSSR, “O razvitii zhilishchnogo stroitel’stva v SSSR (Postanovlenie, 31 iiulia 1957 gg.),” Arkhitektura SSSR, no. 9 (1957): 1-6

Van der Meeren, Willy.1958. "Wonen op de algemene Wereldtentoonstelling van Brussel 1958," Habiter 7 (December): 29-34.

Vasil'ev, A. 1957. "Proekt pavil'ona SSSR na Mezhdunarodnoi vystavke v Briussele,” Arkhitektura SSSR (2): 43-6.

Urry, John 1990. The Tourist Gaze: Leisure and Travel in Contemporary Societies. London: Sage, 4-10.

$\underline{\text { Archives }}$

State Archive of the Russian Federation- GARF

Fond 9470 (Materials of Soviet section of Brussels World Fair 1958), opis (catalogue) 1, dela (files) 1,3,9,10,11,16,18,21,22,25,27 (henceforth

GARF9470/1/1 etc.)

Fond 9518 (State Committee for Cultural Links with Foreign Countries)

opis 1, dela 588, 590, 611

Daily Sketch (London, 1961), cutting in GARF 9518/1/611

Russian State Archive of the Economy - RGAE

Fond 635 (USSR Chamber of Commerce) 
RGAE f. 635, op. 2, dd. 377-390. Otzyvy posetitelei Sovetskogo paviliona na Vsemirnoi vystavke v Briussele (Fourteen volumes of visitors' comments in different languages)

RGAE f. 635, op.1, d. 369, 1. 24. Official photograph album, "Pavil'on SSSR na vsemirnoi vystavke v g. Briussele 1958”

National Archives Record Administration, College Park, MD, USA - NARA

NARA306/1011/1

NARA306/1011/2

NARA306/1050/7

NARA306/71A 2101/159

NARA306/71 A2101/161

The National Archives, London - TNA

TNA FO371 159601. Rudolph Kliks in interview with Vitaly Elistratov, "The USSR’s Biggest Fair Ever” (nd., c. early July 1961),

TNA BW2/532. Confidential memo regarding possible Daily Mail "Ideal Home” Exhibition in Moscow (18 Nov. 1957).

\footnotetext{
${ }^{1}$ Space constraints prohibit fuller discussion of the pavilion architecture here. See (e.g.) Cooke 2007, 188; Devos 2009; Devos 2015, 133-60; Reid 2010; Nikolaev and Mel’nikov 1963; Gradov 1959.
} 